Печенкін Ігор Віталійович аспірант кафедри інформаційної політики та цифрових технологій Національної академії державного управління при Президентові України, 20, вул. Ежена Потьє, м. Київ, 02000, тел.: (044) 48121-63, e-mail: proky@ukr.net, https://orcid.org/0000-0002-64097695

\title{
РОЗВИТОК ТА ШЛЯХИ ВДОСКОНАЛЕННЯ ПРАВОВОГО РЕГУЛЮВАННЯ МЕХАНІЗМІВ ОСКАРЖЕННЯ СЕРВІСНОЇ ДІЯЛЬНОСТІ ОРГАНІВ ПУБЛІЧНОЇ ВЛАДИ
}

Анотація. Формування та реалізація сервісно-орієнтованої державної політики полягає у чутливому відношенню до потреб людини як споживача послуг в різних сферах життя та реалізації соціального забезпечення 3 безумовним дотриманням при цьому його конституційних прав і свобод.

У статті досліджено окремі аспекти розвитку та наведені можливі шляхи вдосконалення механізмів оскарження надання публічних послуг, а також інших результатів сервісної діяльності органів публічної влади.

Сучасне сприйняття поняття сервісної державної політики впевнено приходить на зміну старої моделі концепції державного управління як допоміжної функції з надання «адміністративної послуги». На зміну має бути впроваджені зміни ставлення до ролі громадянина у його взаємовідносинах 3 владою на основі нової «моделі адміністрації як служби гарантованого сервісу» або теорії сервісної держави.

Ефективна державна політика формування і реалізації управлінських послуг та участі в цьому громадянина має стати основним напрямом цифрової трансформації публічного управління та розвитку курсу на суцільне забезпечення прав та законних інтересів людини, переосмислення функцій органів публічної влади відповідно до тенденцій суспільного розвитку.

Ключові слова: органи публічної влади, сервісна діяльність, адміністративні послуги, правове регулювання, механізми оскарження.

Pechenkin Ihor Vitaliiovych Postgraduate Student of the Department of Information Policy and Digital Technologies of the National Academy of Public Administration under the President of Ukraine, 20, Eugene Potier St., Kyiv, 02000, tel.: (044) 481-21-63, e-mail: proky@ukr.net, https://orcid.org/0000-000264097695 


\title{
DEVELOPMENT AND WAYS OF IMPROVEMENT OF LEGAL REGULATION OF MECHANISMS OF APPEALS OF SERVICE ACTIVITY OF PUBLIC AUTHORITIES
}

\begin{abstract}
The formation and implementation of service-oriented state policy is a sensitive attitude to human needs as a consumer of services in various spheres of life and the implementation of social security with unconditional observance of his constitutional rights and freedoms.

The article examines some aspects of development and presents possible ways to improve the mechanisms for appealing the provision of public services, as well as other results of service activities of public authorities.

The modern perception of the concept of service public policy confidently replaces the old model of the concept of public administration as an ancillary function for the provision of "administrative services". Instead, changes in the attitude to the role of the citizen in his relationship with the government should be introduced on the basis of a new "model of administration as a service of guaranteed service" or the theory of the service state.

Effective state policy of formation and implementation of management services and citizen participation should be the main direction of digital transformation of public administration and development of the course to ensure the full rights and legitimate human interests, rethinking the functions of public authorities in accordance with social development trends.
\end{abstract}

Keywords: public authorities, service activities, administrative services, legal regulation, appeal mechanisms.

Постановка проблеми. Процес отримання публічної послуги має бути доступним та структурованим, саме тому за умов сьогодення бракує чіткого роз'яснення суті, порядку надання, доступу та користування публічними послугами. Публічні послуги мають стати частиною державної концепції сервісної державної політики, яка має відповідати обов'язковим для України міжнародним нормам та бути реалістичною, конкретною, ефективною i прозорою для контролю її виконання.

Практика надання публічних послуг викликає обгрунтовану критику і зумовлює необхідність правової регламентації застосування механізмів оскарження сервісної діяльності органів публічної влади, а також розв'язання проблем недостатньої обізнаності громадян та посадових осіб органів публічної влади про складові формування сервісно-орієнтованої державної політики по відношення до надання послуг органами публічної влади. Для цього необхідно розкрити складові історії розвитку, а також розкрити специфічні особливості механізму оскарження надання цифрових управлінських послуг.

Швидке та якісне користування інформацією, відкритості і прозорості даних сприятиме розвитку економіки за міжнародними стандартами Індустрії 4.0., дозволить забезпечити цифрову трансформацію публічного управління. Механізми оскарження сервісної діяльності вдосконалить контроль за 
відкритістю та прозорістю прийняття і реалізації управлінських рішень, допоможе протидіяти корупції, надасть змогу для зростання людського потенціалу і конкурентоспроможності.

Аналіз останніх досліджень і публікацій. Науково-теоретичному обгрунтуванню правових засад забезпечення сервісної діяльності органів публічної влади та формуванню іiі правових засад присвячені наукові дослідження В. Бакуменка, Р. Бойко, Є. Бородіна, Т. Буренко, Ю. Даньшиної, С. Дембицької, В. Дрешпака, Н. Гончарук, Н. Грицяк, Е. Карловської, А. Каляєва, О. Кучабського, А. Ліпенцева, В. Михайлишина, В. Місюри, О Морозової, Л. Прокопенка, А. Семенченка, В. Тертички. Окремі аспекти цифровізації публічного управління досліджували вітчизняні науковці: Г. Аванесова, Є. Архіпова, А. Асанова, Є. Бабаблик, І. Бачило, О. Бухатий, В. Гудницький, Ю. Дубровін, Т. Запорожець, Е. Карловська, О. Карпенко, В. Куйбіда, Я. Коженко, В. Наместнік, А. Осьмак, М. Павлов, О. Серенок, Е. Талапіна, В. Тертичка, Л. Федулова, С. Чукут, Н. Шамрай, а також іноземні науковці А. Вільямс, С. Бастоу, С. Бренен, Х. Гімплей, П. Данлеві, Н. Краузе, Д. Креіс, Х. Маргетс, А. Матеі, Т. Міглані, Х. Навіо-Марко, А. Паломо-Наварро, 3. Полковські, М. Пучек, А. Раду, Е. Форстхоф, К. Шадибеков.

Мета статті. У статті досліджено історичні етапи розвитку та наведені сучасні позитивні практики, а також можливості правого вдосконалення врегулювання механізмів оскарження надання послуг як результат здійснення сервісної діяльності органів публічної влади.

Виклад основного матеріалу. Право на звернення вперше законодавчо було передбачено у Франції за результатами розвитку демократичних свобод громадянина та законодавчого їх закріплення, отриманих після французької революції. У подальшому таку можливість називали правом скарги. 3 юридичної точки зору право скарги стало означати, що воно представлене, як законодавчо передбачене логічне доповнення інших матеріальних суб'єктивних прав громадян. Тобто, кожний громадянин має право не бути жертвою свавільного рішення зі сторони посадових осіб, він має право оскаржити їх незаконні дії, а також має правові гарантії у тому, що не буде переслідуватися.

Сформувавшись як суб'єктивне, право скарги дало поштовх до виникнення у XIX столітті у країнах Західної Європи адміністративної юстиції - особливого виду судової діяльності, пов'язаного з захистом прав громадянина за його скаргою у захисті від необгрунтованих дій суб'єктів публічного управління.

В Україні право скарги, як суб’єктивне право, було закріплено у законодавстві у другій половині XIX століття, а основними джерелами розвитку нормативного регулювання цієї сфери в історії Україні радянського періоду можемо відзначити наступні: постанову VI Всеросійського надзвичайного з’їду Ради від 10 листопада 1918 року «Про чітке дотримання законів», яка проголосила право кожного громадянина оскаржити дії будьякої посадової особи; Указ Президії Верховної Ради СРСР від 12.04.1968 
року. «Про порядок розгляду пропозицій, заяв і скарг»; стаття 58 Конституції СРСР, яка закріплювала право громадян оскаржувати дії посадових осіб, державних і громадських органів; Закон СРСР від 30.06.1987 року «Про порядок оскарження у суді неправомірних дій посадових осіб, які утискають права громадян» .

В сучасній Україні законодавче врегулювання оскарження дій органів публічної влади реально розпочалось з прийняттям Конституції України, в якій передбачені права людини і громадянина у цій сфері та обов'язки органів публічної влади щодо їх забезпечення. В подальшому розвиток реалізації цих прав було забезпечено нормами Закону України «Про звернення громадян» від 2 жовтня 1996 року №393/96-ВР, який й досі регулює питання практичної реалізації конституційного права громадянами вносити в органи публічної влади, пропозиції про поліпшення їхньої діяльності, викривати недоліки в роботі, оскаржувати дії посадових осіб, державних і місцевих органів влади. Однак в даний час правове забезпечення його виконання викликає обгрунтовану критику та потребує оновлення.

Завдяки законодавчо передбаченій правовій основі скарга набуває якості правового засобу на ряду з іншими засобами контролю за діяльністю апарату органів публічної влади. Тільки на відміну від інших засобів, в процесі подання та при здійсненні контролю за результатами розгляду скарги зазначені механізми оскарження сервісної діяльності мають ефективніше використовуватися громадянином в процесі цифрової трансформації публічного управління., що потребує вдосконалення правового регулювання. Завдяки цифровим можливостям функція скарги може бути вдосконалена: під час захисту свої права i інтересів проти будь-якого адміністративного свавілля; має стати унікальною i універсальною зброєю самозахисту громадян; право оскаржити дії посадової особи удосконалюючи тим ефективність їх роботи; аналіз розгляду скарг може стати підставою для притягнення посадової особи до встановленої законом відповідальності.

Результати історичного розвитку правовідносин між державою i громадянином в даний час надають нових можливостей впливу на процес прийняття i реалізації рішень органів публічної влади встановленням сучасних ефективних засобів громадського контролю. Впровадження інформаційно-комунікативних технологій (далі IKT) у діяльності органів публічної влади стрімкими темпами у світі прямує до цифровізації публічного управління. Даному етапу передували етапи інформатизації державного управління та електронного урядування. Така діяльність має бути науково обгрунтована та законодавчо врегульована. Взаємодія органів влади та громадянського суспільства й окремого громадянина зокрема безперервно змінюються i вдосконалюється, що, безумовно, являється складовою цивілізаційного сучасного розвитку. Сервісна державна політика у забезпеченні взаємодії держави і громадянина потребує технологічного забезпечення в бік осучаснення. Вплив громадянина на процес прийняття i реалізації управлінських рішень повинен набути не декларативного статусу, а реального правого i технологічного механізму оскарження прийнятого 
рішення або наданої адміністративної послуги органами публічної влади шляхом цифровізації публічного врядування.

Цифровізація - це процес впровадження інформаційно-комунікативних технологій для вдосконалення життєдіяльності людини, суспільства та держави, а політика сервісної діяльності полягає у введенні єдиних стандартів для зберігання і використання інформації; об'єднанні баз даних органів влади на єдиних інформаційних платформах; інтероперабельності цих систем; забезпечення умов для широкого доступу до них. Забезпечення швидкого користування інформацією, відкритості i прозорості даних сприятиме розвитку економіки за міжнародними стандартами Індустрії 4.0.[1], реформуванню публічного управління, відкритості та прозорості прийняття і реалізації рішень, протидії корупції, надасть змогу для зростання людського потенціалу i конкурентоспроможності, пришвидшить процес децентралізації в Україні.

Процес оскарження рішень, дій або бездіяльності суб'єктів публічної влади має судовий та позасудовий (адміністративний) рівень, що унормовано нормативними актами адміністративного права та іншими нормами, однак низка наукових проблем залишається недостатньо розробленими а процесуальні форми недолугими та малоефективними. Серед наукових проблем можна назвати відсутність концептуального, цілісного бачення змісту оскарження, механізму оскарження і досить різноманітне вживання самого терміну «оскарження», а також невирішеність низки питань правового регулювання процедур оскарження.

Основними 3 них є унормування загальних та спеціальних процедур судового оскарження, зв'язки між судовим та адміністративним оскарженням і регламентацію оскарження в адміністративно-юрисдикційній сфері, непрямі позасудові можливості оскарження (діяльність третейських судів, арбітражний процес, звернення зі скаргою до Уповноваженого Верховної Ради України з прав людини, Конституційного суду та інш.).

Окремим питанням постає наукове обгрунтування та нормативне визначення поняття «послуга» та порядок можливості впливу на управлінську послугу громадянином. Таке право можуть реалізовувати через механізм оскарження приватні особи, які перебувають чи можуть перебувати у правовідносинах з органами публічної влади, їх посадовими особами, іншими владними суб'єктами, здатні домогтися скасування чи визнання протиправним певного рішення, дії чи бездіяльності. У свою чергу вплив, який чинять приватні особи на суб'єктів публічно-владних повноважень через механізм оскарження, має й більш широке значення, оскільки за його допомогою відбувається «зворотний» зв'язок суспільства і держави, корегуються певні рішення суб'єктів публічно-владних повноважень, їх правозастосовна практика, що сприяє забезпеченню верховенства права i демократії в країні. В даний час бракує чіткого налагодженого механізму вироблення державної політики щодо надання послуг органами публічної влади. Найчастіше прийняті нормативно-правові акти носять тимчасовий й суперечливий характер а дії органів публічної влади зосереджуються на 
ситуативних проблемах [2, с.234].

Український вчений А.А. Хлєбніков розглядає послугу як нову якість, що виникає в процесі діяльності, результатом якої є задоволення потреб населення, а ефект від iï надання може бути постійним чи тимчасовим, оборотним і необоротним, фізичним і духовним [3, с.45].

За наведеною ним класифікацією послуги можна поділити на: матеріальні та нематеріальні; за функціональною ознакою: виробничі, споживчі, соціальні, розподільчі; за ступенем матеріальності : матеріальні та нематеріальні; за рівнем значущості: основними та додатковими; за терміном дії; кінцеві та постійні; за критерієм законності : в рамках та поза унормованого чинного законодавства; за економічними ознаками: ринкові та неринкові, комерційні та некомерційні, платні та безплатні; за формою власності: вироблені господарюючим суб’єктом приватної власності або державними і комунальними підприємствами та організаціями; за способом доставки споживачу: пов'язані 3 інвестиціями, торгівлею, інвестиціями і торгівлею; за участю в міжнародному обміні: об'єктів зовнішньої торгівлі, які не можуть бути предметом експорту та тих, які виробляються для внутрішнього споживання й на експорт; за формою обслуговування: абонементного обслуговування, термінове, але за місцем проживання, роботи,відпочинку; за рівнем суб'єкта надання: державними, регіональними, місцевими; за способом фінансування: бюджетні, позабюджетні; за формою обліку: враховані, невраховані.

Управлінські послуги можна розглядати як процес, і як результат. Як процес послуги представляють собою діяльність, спрямовану на задоволення потреб їх споживачів. У процесі надання послуг не створюється новий, раніше не існуючий матеріальний продукт, але змінюється якість вже створеного продукту. Як результат - вони є благами, наданими не у вигляді речей, товарів, а у формі діяльності. Характеристики послуг: недовговічність, невідчутність, невіддільність, мінливість якості, під час надання послуги не передаються права власності.

У той же час нормативно-правове регулювання визначення та надання послуг в Україні не регулює поняття «управлінська послуга», а здійснюється відповідно до вимог Законів України «Про адміністративні послуги» [4].

Окрім того, необхідно зазначити про те, що у вітчизняній та зарубіжній літературі на даний момент не сформовано загальноприйняте визначення поняття соціальної послуги. У Законі України «Про соціальні послуги» визначено, що «соціальні послуги - це комплекс заходів 3 надання допомоги особам, окремим соціальним групам, які перебувають у складних життєвих обставинах і не можуть самостійно їх подолати, з метою розв'язання їхніх життєвих проблем» [5].

Потрібно зазначити про осучаснення та наявність прогресу в цій сфері в даний час. Цифрова трансформація стає пріоритетом розвитку держави 3 вжиттям послідовних та ефективних кроків 3 інституційних змін іiі впровадження. Оскільки питання цифровізації публічного управління, разом зі зміною відношення до якості надання адміністративних послуг було 
забюрократизовано, на базі Державного агентства 3 питань електронного урядування України створено Міністерство цифрової трансформації України, а його очільник займає посаду Віце-прем'єра в Уряді.

Відповідно до постанови КМУ від 18.09.2019 року №856 міністерство стає головним органом 3 формування і реалізації державної політики у сферах: цифровізації, цифрового розвитку, цифрової економіки, цифрових інновацій, електронного урядування, електронного демократії, розвитку інформаційного суспільства, інформатизації; у сфері розвитку цифрових навичок у громадян та цифрових прав громадян; у сферах відкритих даних розвитку національних інформаційних ресурсів та інтероперабельності, розвитку інфраструктури широкосмугового доступу до Інтернету та телекомунікації, електронної комерції та бізнесу; у сфері надання електронних та адміністративних послуг; у сферах електронних довірчих послуг та електронної ідентифікації; у сфері розвитку IT- індустрії.

На розвиток цифровізації публічного управління націлена в даний час політика Уряду країни, тому розпорядженням Кабінету Міністрів України від 02.12.2020 року №1556-р була схвалена Концепція розвитку штучного інтелекту в Україні, якою передбачені шляхи і способи розв'язання проблем у ключових сферах державної політики. Цим документом передбачено забезпечення: виконання завдань 3 формування переліку адміністративних послуг, рішення за якими приймаються автоматично; запровадження діалогового інтерфейсу для електронних адміністративних послуг; розвитку технологій штучного інтелекту для: цифрової ідентифікації та верифікації осіб, проведення аналізу, прогнозування та моделювання розвитку показників ефективності системи публічного управління, з метою виявлення випадків неправомірного втручання у діяльність державних електронних систем; виявлення недобросовісної практики в діяльності посадових осіб та державних службовців за різними напрямами шляхом проведення аналізу текстів управлінських рішень та інших даних, які формуються в комп’ютеризованих системах/реєстрах під час провадження такої діяльності.

9 березня 2021 року Свропейською Комісією в Брюсселі прийнято нову Стратегію цифрової трансформації Свропи до 2030 року та шляхи їх досягнення -«Європейське цифрове десятиріччя»[6]. Свропейська Комісія пропонує запровадити цифровий компас для Свропи для втілення цифрових амбіцій ЄС до 2030 року в конкретні строки реалізації за чотирма напрямами: досягнення громадянами цифрових навиків; безпечні, продуктивні і стійкі цифрові інфраструктури; цифрова трансформація бізнесу; цифровізація державних послуг.

В науковому та експертному середовищі предметно обговорюється розвиток стратегічного рішення про перехід до шостого технологічного укладу виробництва, який має бути завершений не пізніше ніж до 2050 року 3 паралельним забезпеченням перебудови нового типу економіки та розробки інструментів іiі захисту. Освоєння шостого технологічного укладу, характеризується розвитком когнітивних, соціогуманітарних, освітніх технологій, нанобіотехнологій, пов'язаних як 3 виробництвом продуктів 
харчування, так і з медициною і фармацевтикою і заснованих на досягненнях молекулярної хімії, біології та генної інженерії; систем штучного інтелекту і квантових технологій; глобальних інформаційних мереж i цифрових технологій; інтегрованих високошвидкісних транспортних систем; нових видів і способів отримання енергії. В даний час вже 60\% транснаціональних компаній перейшли на використання цифрових технологій у відповідь на сучасні загрози, які викликані карантинними світовими обмеженнями, викликаними епідемію вірусу COVID-19.

Існують два сценарію цифрової трансформації держави - еволюційний та форсований, тому з огляду на певну відсталість від виконання перелічених міжнародно-правових актів та стратегій розвитку цифрової трансформації публічного управління, а саме в частині забезпечення ефективного використання механізмів оскарження сервісної діяльності, постає потреба у стрибкоподібному розвитку та цифрової трансформації України. Саме до цього спонукає загальносвітова пандемія та карантинні заходи, які змушують перевести роботу та спілкування з органами публічної влади у дистанційний режим та зобов'язують розробити інструменти дистанційного впливу на процеси обслуговування ними споживачів адміністративних послуг, оскарження результатів такої діяльності.

Про результативність таких дій зможуть свідчити реальний вплив громадянина на послугу, а в цілому сприятиме цифровим трансформаціям, передусім в публічному управлінні та економіці. Показники такої компетенції, які свідчать про готовність держави до впровадження цифрових технологій порівнюючи стан іiі розвитку із заздалегідь визначеними критеріями, дозволяють в подальшому реалізовувати свої стратегічні наміри. Дозволяють здійснити таку оцінку індикатори Індексу Цифрової Еволюції (Digital Evolution Index) [7] - цілісної оцінки прогресу цифрової економіки, що поєднує близько ста показників за чотирма напрямами: умови постачання (Supply Conditions), цифрових технологій або мережевих можливостей, умови попиту (Demand Conditions), інституційне середовище. (Institutional Environment) та інноваційні зміни (Innovation and Change).

Саме для підвищення таких рейтингів і показників потрібно змінювати якість надання послуги та сприяти розвитку механізмів оскарження сервісної діяльності органів публічної влади. Для цього необхідно дотримуватися вимог міжнародних норм щодо забезпечення стандартизації державної служби. Найбільш поширеною основою для створення таких систем $є$ міжнародний стандарт ISO 9001, який був переглянутий та прийнятий Україною до національних стандартів за абревіатурою ДСТУ ISO 18091:2020 який набуває чинності 3 01.06.2020 року згідно наказу ДП «Український науково-дослідний і навчальний центр проблем стандартизації, сертифікації та якості» від 25.11.2020 р. №408 [6], а його вимірювання здійснює Центр адаптації державної служби до стандартів Свропейського Союзу Національного агентства України з питань державної служби та публікує звіти про обстеження систем управління якістю в органах влади (у тому числі надання адміністративних послуг) [8]. 
3 метою визначення якості, ефективності та результативності послуги у світі визнано використовувати інструменти TQM [9] ( модель загального управління якістю - тобто філософії управління постійного підвищення якості послуг з метою повного задоволення споживача послуг, оптимального використання ресурсів, а також задоволення від власної роботи працівників що приводить до отримання надійних та інноваційних послуг споживачам). Також використовують модель загальної оцінної рамки (Common Assessment Framework, CAF) - це сумісний продукт 15 міністерств країн $\mathrm{CC}$, які діють у сфері публічного управління, головна мета якого забезпечення достатньо простого визначення місця органу публічної влади в рамці самооцінки організації державного сектору.

Висновки. Проведеним дослідженням здійснено науково-теоретичне обгрунтування необхідності вдосконалення окремих аспектів правового регулювання оскарження сервісної діяльності органів публічної влади в Україні, розробки та вдосконалення напрямів прозорого контролю за якістю надання послуг.

Доведено, що цифровізація публічного управління являється важливим напрямом як наукових досліджень, так і практико-орієнтованої діяльності, що потребує єдиного трактування міжнародно-правових норм, ратифікованих Україною.

Сучасні політичні, соціально-економічні та інформаційно-комунікативні інструменти взаємодії держави і суспільства в Україні безперервно вдосконалюються під впливом нових викликів, що спричиняють зміни процесів вироблення державної політики, яка у своєму еволюційному розвитку потребує як переосмислення традиційних управлінських підходів, так i застосування нових сервісно-орієнтовних механізмів щодо іï формування та реалізації.

\section{Лimepamypa:}

1. Асоціація підприємств промислової автоматизації в Україні. Індустрія 4.0 в Україні. URL: https://industry4-0-ukraine.com.ua

2. Карпенко О.В. Управлінські послуги в Україні: механізми надання органами влади / О.В. Карпенко. - К.: АМУ, 2014. С.234. - 408 с.

3. Хлєбніков А.А. Розвиток системи надання публічних послуг в Україні. дис.к.н.держ.упр. 25.00.02. // А.А. Хлєбніков. ХРІДУ НАДУ при Президентові України. X.: 2019. C.45. 212 c.

4. Про адміністративні послуги : Закон України від 06.09.2012 № 5203-VI // Відомості Верховної Ради. 2013. № 32. Ст. 409. URL: https://zakon.rada.gov.ua/laws/show/5203-17

5. Про соціальні послуги. Закон України від 17.01.2019 р. №2671-VIII. URL: https://zakon.rada.gov.ua/laws/show/2671-19\#Text

6. Стратегія. Європейське цифрове десятиріччя. Міжнародний документ. Брюссель. 09.03.2021. URL: https://ec.europa.eu/commission/presscorner/detail/en/IP_21_983

7. Індекс Цифрової Еволюції. URL:https://newsroom.mastercard.com/eu/files/2014/09/ Digital-Evolution-Index_MC-Key-Findings-FINAL.pdf

8. ДСТУ ISO 18091. Упровадження та сертифікація систем управління якістю надання послуг. URL: https://zakon.rada.gov.ua/rada/show/v0408774-20\#Text 
9. Центр адаптації державної служби. URL: http://www.center.gov.ua

10. Total Quality Management. URL: https://www.progressive-management.com.ua/tqmtotal-quality-management

\section{References:}

1. Asotsiatsiia pidpryiemstv promyslovoi avtomatyzatsii v Ukraini. Industriia $4.0 \mathrm{v}$ Ukraini [Association of Industrial Automation Enterprises in Ukraine. Industry 4.0 in Ukraine]. industry4-0-ukraine.com.ua. Retrieved from https://industry4-0-ukraine.com.ua [in Ukrainian].

2. Karpenko, O.V. (2014). Upravlinski posluhy v Ukraini: mekhanizmy nadannia orhanamy vlady []. Kyiv: AMU [in Ukrainian].

3. Khliebnikov, A.A. (2019). Rozvytok systemy nadannia publichnykh posluh v Ukraini [Development of the public service delivery system in Ukraine]. Candidate's thesis. Kharkiv: KhRIDU NADU pry Prezydentovi Ukrainy [in Ukrainian].

4. Zakon Ukrainy "Pro administratyvni posluhy" : vid 06.09.2012, № 5203-VI [Law of Ukraine "On administrative services" from 06.09.2012, № 5203-VI]. (2013). Vidomosti Verkhovnoi Rady - Bulletin of the Verkhovna Rada, 32. Art. 409. Retrieved from https://zakon.rada.gov.ua/laws/show/5203-17 [in Ukrainian].

5. Zakon Ukrainy "Pro sotsialni posluhy" : vid 17.01.2019 r., № 2671-VIII [Law of Ukraine "About social services" from January 17 2019, № 2671-VIII]. zakon.rada.gov.ua. Retrieved from https://zakon.rada.gov.ua/laws/show/2671-19\#Text [in Ukrainian].

6. Europe's Digital Decade: Commission sets the course towards a digitally empowered Europe by 2030. (2021). ec.europa.eu. Retrieved from https://ec.europa.eu/commission/ presscorner/ detail/en/IP_21_983 [in English].

7. Digital Evolution Index. The Next Billion Consumers Move Onto the Global Stage. (2014). newsroom.mastercard.com. Retrieved from https://newsroom.mastercard.com/eu/files/ 2014/09/ Digital-Evolution-Index_MC-Key-Findings-FINAL.pdf [in English].

8. Uprovadzhennia ta sertyfikatsiia system upravlinnia yakistiu nadannia posluh [Implementation and certification of quality management systems for services]. DSTU ISO 18091. Retrieved from https://zakon.rada.gov.ua/rada/show/v0408774-20\#Text [in Ukrainian].

9. Tsentr adaptatsii derzhavnoi sluzhby [Civil Service Adaptation Center]. www.center.gov.ua. Retrieved from http://www.center.gov.ua [in Ukrainian].

10. Total Quality Management. www.progressive-management.com.ua. Retrieved from https://www.progressive-management.com.ua/tqm-total-quality-management [in Russian]. 